\title{
Rencontre de partage sur la problématique des grossesses non désirées chez les adolescents/jeunes au Sénégal : Compte rendu de rencontre
}

\author{
Babacar Mane \\ Population Council \\ Marie-Jesus Buabey \\ Nafissatou Diop \\ Population Council \\ Patrick Mugirwa
}

Follow this and additional works at: https://knowledgecommons.popcouncil.org/departments_sbsr-rh

Part of the Demography, Population, and Ecology Commons, Family, Life Course, and Society Commons, Gender and Sexuality Commons, International Public Health Commons, Maternal and Child Health Commons, and the Women's Health Commons How does access to this work benefit you? Let us know!

\section{Recommended Citation}

Mane, Babacar, Marie-Jesus Buabey, Nafissatou Diop, and Patrick Mugirwa. 2016. "Rencontre de partage sur la problématique des grossesses non désirées chez les adolescents/jeunes au Sénégal : Compte rendu de rencontre," STEP UP Meeting Report. Dakar: Population Council. 
STEP

STRENGTHENING EVIDENCE FOR PROGRAMMING ON UNINTENDED
PREGNANCY
SENEGAL

Rapport de

Rencontre

Juin 2016

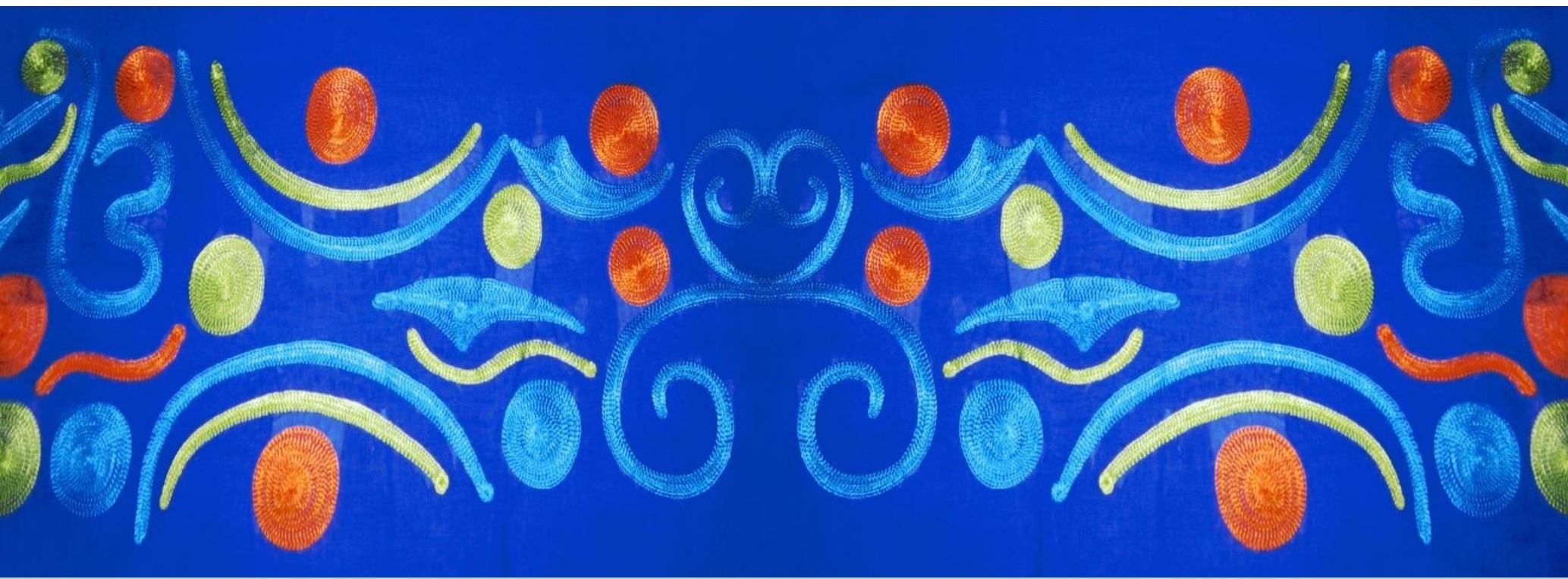

Rencontre de partage sur la problématique des grossesses non désirées chez les adolescents/jeunes au Sénégal

Dakar, 02 juin 2016

\section{Compte rendu de rencontre}

BABACAR MANE, MARIE-JESUS BUABEY, NAFISSATOU DIOP, PATRICK MUGIRWA

NT/

UKaid

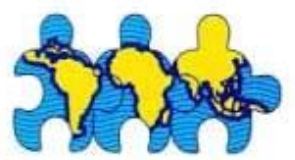

PARTNERS IN POPULATION AND DEVELOPMENT

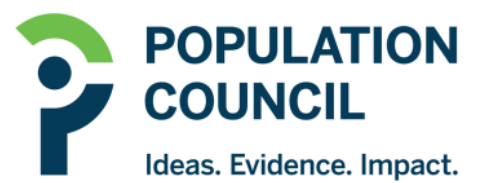




\title{
Rencontre sur la problématique des grossesses non désirées chez les adolescents/jeunes au Sénégal
}

\author{
Dakar, 02 juin 2016
}

\section{Compte rendu de rencontre}

BABACAR MANE', MARIE-JESUS BUABEY², NAFISSATOU DIOP³ ${ }^{3}$ PATRICK MUGIRWA4

1 Consultant, Population Council, Sénégal

2 Division de la Santé Sexuelle et Reproductive des Adolescent(e)s/Jeunes. Direction de la Santé de la Reproduction et de la Survie de l'Enfant (DSRSE). Ministère de la Santé et de l'Action Sociale, Sénégal

3 Population Council, Sénégal

4 Partners in Population and Development Africa Regional Office (PPD ARO)

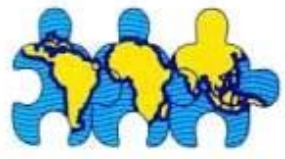

PARTNERS IN POPULATION AND DEVELOPMENT
POPULATION COUNCIL

Ideas. Evidence. Impact. 


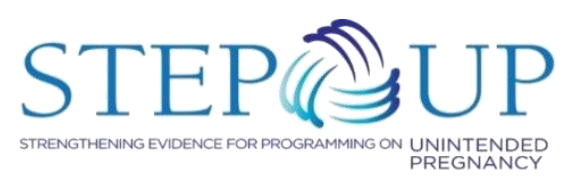

STEP UP œuvre en faveur d'une recherche pertinente à l'élaboration des politiques afin de promouvoir une approche basée sur des données pour améliorer l'accès à la planification familiale et à l'avortement sans risque. Nous travaillons au Bangladesh, dans la partie Nord de I'Inde, au Ghana, au Kenya et au Sénégal. STEP UP est coordonné par le Population Council en partenariat avec African Population and Health Research Center; icddr,b; London School of Hygiene and Tropical Medicine; Marie Stopes International; et Partners in Population and Development. STEP UP est financé par UKaïd du Gouvernement du Royaume Uni. www.stepup.popcouncil.org

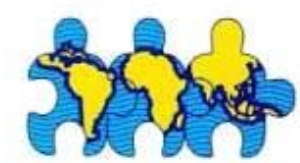

PARTNERS IN POPULATION AND DEVELOPMENT

Le PPD est une initiative intergouvernementale lancée en 1994 à la Conférence Internationale sur la Population et le Développement. II comprend des pays membres de partout dans le monde, et fut créée dans le but d'étendre et améliorer la collaboration sud-sud dans les domaines de la santé de la reproduction, de la population et du développement. www.partners-popdev.org

\section{POPULATION COUNCIL \\ Ideas. Evidence. Impact.}

Le Population Council s'attelle aux questions cruciales de la santé et du développement - qu'il s'agisse d'endiguer la progression du VIH, d'améliorer la santé reproductive et d'offrir aux jeunes la promesse d'une vie satisfaisante et productive. Par ses travaux de recherche en biomédecine, en sciences sociales et en santé publique dans 50 pays, il s'efforce d'apporter avec ses partenaires des solutions qui conduisent à des politiques, des programmes et des technologies plus efficaces, pour améliorer la vie partout dans le monde. Fondé en 1952, le Population Council est une organisation non gouvernementale à but non lucratif. II siège à New York sous la conduite d'un conseil d'administration international. www.popcouncil.org

Citation recommandée: Babacar Mané, Marie-Jésus Buabey, Nafissatou Diop \& Patrick Mugirwa. 2016. "Rencontre de partage sur la problématique des grossesses non désirées chez les adolescents/Jeunes au Sénégal. Dakar 02 juin 2016. Compte-rendu de rencontre", Rapport de rencontre. STEP UP Meeting Report. Dakar: Population Council.

\section{(C) 2016, Population Council}

Pour plus d'informations, veuillez contacter:

Dr. Harriet Birungi, hbirungi@popcouncil.org

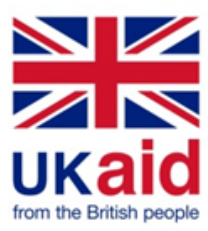




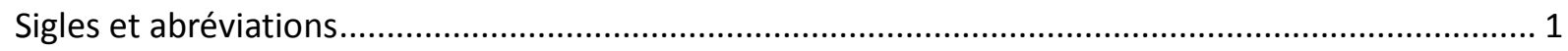

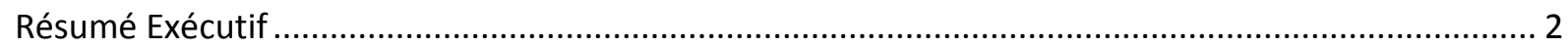

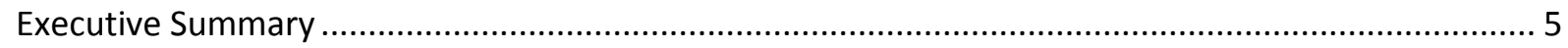

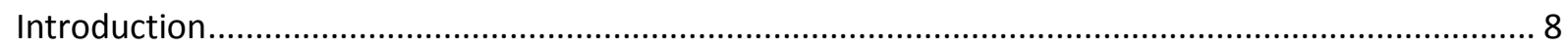

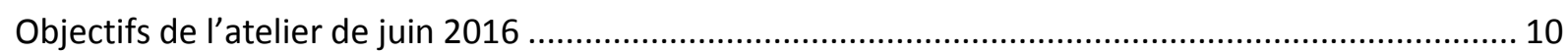

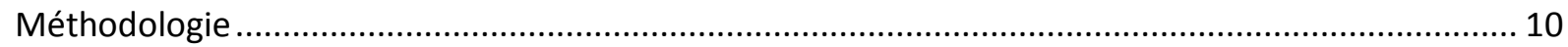

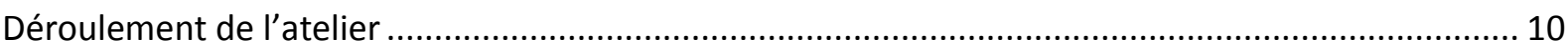

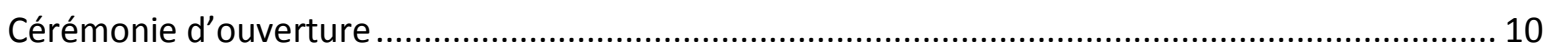

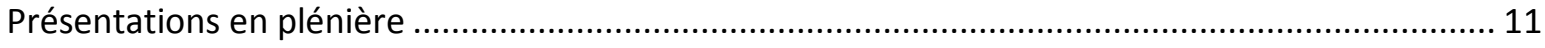

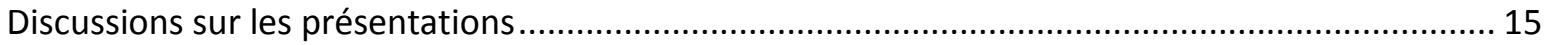

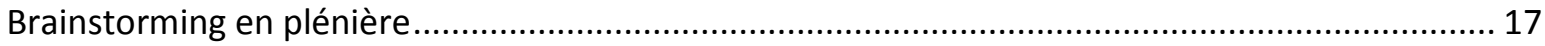

Résumé des recommandations et actions à entreprendre ................................................................. 19

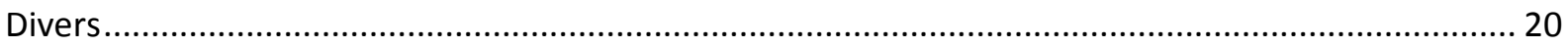

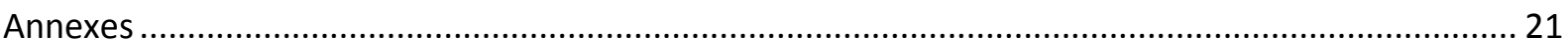

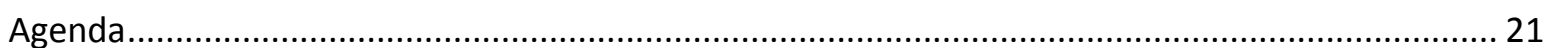

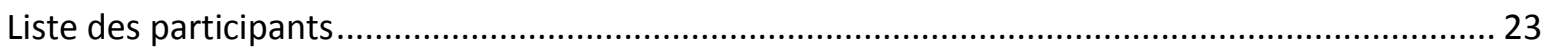




\section{Sigles et abréviations}

$A D$

ASBEF

ASGO

CCA

DCMS

DFID

DGS

DPP

DSRSE

EDS

EVF

GND

IPDSR

ISF

ISSU

MSAS

MST

NTIC

ODD

OMS

PARC

PC

PF

PPD

PPD ARO

PPJ

PSE

SAA

SNEIPS

SR

SR/PF

SR/SE

SRAJ

SSR

STEP UP

VIH
A Déterminer

Association Sénégalaise pour le Bien-Etre Familial

Association Sénégalaise des Gynécologues/Obstétriciens

Centre Conseils Adolescents

Division du Contrôle Médical Scolaire

Department for International Development

Directeur Général de la Santé

Déclaration de Politique de Population

$$
\text { Direction de la Santé de la Reproduction et de la Survie de l'Enfant }
$$

Enquête Démographique et de Santé

Education à la Vie Familiale

Grossesses Non Désirées

Institut Population, Développement et Santé de la Reproduction

Indice Synthétique de Fécondité

Initiative Sénégalaise de Santé Urbaine

Ministère de la Santé et de l'Action Sociale

Maladies Sexuellement Transmissibles

Nouvelles Technologies de l'Information et de la Communication

Objectifs de Développement Durable

Organisation Mondiale de la Santé

Projet d'Appui à la Révision des Curricula

Population Council

Planification Familiale

Partners in Population and Development

Partners in Population and Development Africa Regional Office

Projet Promotion des Jeunes

Plan Sénégal Emergent

Soins Après Avortement

Service National de l'Education et de l'Information pour la santé

Santé de la Reproduction

Santé de la Reproduction/ Planification Familiale

Santé de la Reproduction/ Survie de l'Enfant

Santé de la Reproduction des Adolescents et des Jeunes

Santé Sexuelle et Reproductive

Strengthening Evidence for Programming on Unintended Pregnancy

Virus d'Immunodéficience Humaine 


\section{Résumé Exécutif}

En juin 2015, la Direction de la Santé de la Reproduction et de la Survie de l'Enfant (DSRSE) du Ministère de la Santé et de l'Action Sociale (MSAS), le Population Council, et Partners in Population and Development Africa Regional Office (PPDARO), avaient co-organisé un atelier de partage des résultats de l'étude 'Comprendre les grossesses non désirées au Sénégal-Profil-pays". Cet atelier qui avait ciblé les parlementaires et acteurs clés de la société civile avait pour objectifs de :

- Informer les décideurs sur les défis actuels du programme de Santé de la Reproduction et Survie de l'Enfant (SR/SE) et les problèmes prioritaires.

- Susciter l'engagement des autorités à la prise de décision pour résoudre les questions prioritaires.

- Engager les autorités à un débat autour des grossesses non désirées chez les adolescentes/jeunes.

Un des thèmes émergents lors de cette journée avait porté sur la problématique des grossesses non désirées (GND) chez les adolescents/jeunes au Sénégal.

L'atelier de juin 2015 avait permis de dégager des pistes d'interventions pour contribuer à mieux adresser les défis qui se posent à l'amélioration de la Santé Sexuelle et Reproductive (SSR) des adolescents/jeunes.

En 2016, la DSRSE, le Population Council et PPD ont convenu de réunir à nouveau les parlementaires et acteurs clés pour faire le suivi de la mise en œuvre des recommandations issues de l'atelier de juin 2015, et d'engager les parties prenantes vers la mise en œuvre de stratégies pour contribuer à l'amélioration de la SSR des adolescents/jeunes.

La rencontre de juin 2016 avait donc pour objectifs de :

\section{Objectif général :}

Faire le point sur la mise en œuvre des recommandations de l'atelier de juin 2015 et d'engager les participants vers la mise en œuvre de stratégies pour contribuer à l'amélioration de la Santé Sexuelle et Reproductive (SSR) des adolescents/jeunes.

\section{Objectifs spécifiques}

- Faire le point sur la mise en œuvre des recommandations de la rencontre de juin 2015.

- S'informer de la situation de la SSR dans les systèmes éducatif et sanitaire ainsi que du rôle de la société civile.

- Réfléchir à l'amélioration des services de SSR et la problématique de l'éducation à la santé sexuelle.

- Formuler des recommandations et développer un plan d'action pour leur mise en œuvre.

La cérémonie d'ouverture a été présidée par le Directeur Général de la Santé (DGS), représentant Madame le Ministre de la Santé et de l'Action Sociale, en compagnie de l'Honorable Député Aimé Assine, Président de la Commission Santé de l'Assemblée Nationale, du Dr. Nafissatou Diop, Directrice-Pays du Population Council, et de Mr. Patrick Mugirwa, Représentant de PPD ARO. Un total de 35 participants, dont 21 femmes et 14 hommes, ont assisté à la rencontre. Neuf (09) parlementaires, un représentant du Conseil Economique, Social et Environnemental (CESE), et des représentants de la société et des institutions partenaires ont rehaussé de leur présence cette importante rencontre. 
La rencontre s'est ensuite déroulée sous deux formats :

- Présentations en plénière.

- Brainstorming en plénière

En vue d'alimenter les discussions, un aperçu global sur la problématique de la SSR des adolescents/jeunes a été présenté par certains acteurs clés :

- Suivi des recommandations de l'atelier de juin 2015 (Population Council)

- Bilan de l'éducation à la santé sexuelle et reproductive dans le système éducatif formel (Division du Contrôle Médical Scolaire -DCMS)

- Offre de services de santé reproductive des adolescents/jeunes dans le système de santé (DSRSE)

- Rôle de la société civile dans l'amélioration de la santé sexuelle et reproductive des adolescents/jeunes (Association Sénégalaise pour le Bien-Etre Familial - ASBEF)

Le brainstorming a ensuite permis d'échanger sur les thématiques suivantes :

- Comment améliorer l'environnement juridique et législatif pour mieux adresser la problématique de la SSR des adolescents/jeunes?

- Quelles stratégies adopter pour des services conviviaux aux adolescents/jeunes ?

- Quels sont les défis, enjeux et perspectives de l'éducation sexuelle et reproductive à l'école ?

Les principales résolutions/actions issues des discussions sont résumées ci-dessous par thématique :

Révision des lois sur la SR/PF et l'avortement:

- Proposition d'une rencontre entre le Comité de plaidoyer pour l'accès à l'avortement médicalisé au Sénégal (plus connu sous le nom de « Taskforce ») et la Commission Santé de l'Assemblée Nationale.

- Implication des autres commissions de l'Assemblée Nationale lors de cette rencontre avec la Taskforce.

- Identification des poches de résistance à l'adoption de la loi dans le cadre des activités de plaidoyer et communication qui seront menées par les parlementaires avec l'appui de la taskforce.

- Renforcement des capacités des parlementaires en communication sur le sujet des GND des adolescents/jeunes.

- Implication des hommes, notamment en répliquant l'initiative "Bajenu Gox" à travers l'initiative "Nidiayu Gox" permettant de les utiliser comme agents communautaires dans le plaidoyer.

- Implication de la société civile qui peut jouer un rôle déterminant pour adresser les résistances au niveau communautaire et des religieux.

- Déroulement d'activités de sensibilisation auprès des communautés pour qu'elles s'approprient les lois qui seront votées. Les parlementaires qui sont en contact permanent avec les populations pourraient jouer un rôle déterminant dans ces activités de sensibilisation.

- Vulgarisation de la loi SR : les parlementaires ont manifesté un intérêt pour appuyer la dissémination de cette loi auprès des communautés.

- Sensibilisation des magistrats et des juges pour une meilleure application des lois 
- Ciblage des Associations Sportives et Culturelles (ASC) au niveau des quartiers pour des actions de vulgarisation des lois en vue de leur appropriation.

Education à la santé de la reproduction au niveau des écoles:

- Réflexion sur la nécessité de donner une éducation à la santé de la reproduction aux enfants pour les préparer à une vie saine. Les enfants ne doivent pas seulement être considérés comme des cibles passives mais comme pouvant être des acteurs de changement.

- Introduction de l'éducation à la santé de la reproduction dès l'élémentaire, adaptée aux besoins et niveaux de compréhension des élèves.

- Mise en place d'un observatoire pour le suivi des GND en milieu scolaire aussi bien au niveau national que régional.

- Recrutement d'assistants sociaux au niveau des écoles pour mieux répondre aux besoins des adolescents/jeunes

- Sensibilisation des parents pour les préparer à aborder ces questions au sein de la famille

- Prise en compte des adolescents/jeunes vivant avec un handicap, notamment les aveugles et les sourdsmuets

- Inclusion des questions émergentes dans le processus de révision des curricula de formation à travers le Projet d'Appui à la Révision des Curricula (PARC) mis en place par le Ministère de l'Education Nationale (MEN)

- Implication des associations de parents d'élèves dans la conception et la mise en œuvre des programmes d'éducation sexuelle et reproductive.

Offre de services SRAJ au niveau des structures de santé et des Centres Conseils Adolescents (CCA):

- Mise en place de mesures d'accompagnement des CCA pour qu'ils puissent mieux répondre aux besoins des adolescents/jeunes.

- Redynamisation du réseau des CCA.

- Renforcement des capacités des acteurs.

- Systématisation d'espaces ados /jeunes dotés d'équipements adéquats dans les structures de santé. 


\section{Executive Summary}

In June 2015, the Directorate of Reproductive Health and Child Survival (DSRSE) of the Ministry of Health and Social Action (MSAS), the Population Council and Partners in Population and Development Africa Regional Office (PPD ARO), co-organized a workshop to share the results of the study "Understanding unwanted pregnancies in Senegal - Country profile". That workshop targeted parliamentarians and key civil society actors. The objectives were to:

- Inform decision-makers on the current challenges of the Reproductive Health and Child Survival (RH / CS) program and its priority issues.

- Stimulate national authorities to commit to address the priority issues.

- Engage a dialogue with key stakeholders around adolescent/youth unwanted pregnancies.

One of the emerging topics from that day was the challenge of unwanted pregnancies among adolescent/youth in Senegal.

The June 2015 workshop enabled the identification of interventions to help better address the challenges to improving adolescent/youth sexual and reproductive health (SRH).

In 2016, the DSRSE, Population Council and PPD agreed to again bring together Parliamentarians and key actors to follow up on the implementation of the recommendations of the June 2015 workshop, and to engage the stakeholders in the implementation of strategies contributing to improving adolescents/youth's SRH.

The objectives of the June 2016 meeting were:

\section{General objective:}

To review the status of implementation of the recommendations from the June 2015 meeting and engage participants towards the implementation of strategies contributing to the improvement of adolescent/youth's Sexual and Reproductive Health (SRH).

\section{Specific objectives:}

- Review the status of implementation of the recommendations from the June 2015 meeting;

- Learn about the situation of SRH in the educational and health systems as well as the role of civil society.

- Reflect on improvements to SRH services and the issue of sexual health education.

- Provide recommendations and develop an action plan for their implementation.

The opening ceremony was presided by the Director General of Health (DGS) representing the Minister of Health and Social Action, along with Honorable Aimé Assine, President of the Health Commission of the National Assembly, Dr. Nafissatou Diop, Population Council Country Director, and Mr. Patrick Mugirwa, PPD ARO Representative. A total of 35 participants, including 21 women and 14 men attended the meeting. Nine (09) parliamentarians, a representative of the Economic, Social and Environmental Council (CESE) and representatives from the civil society and partner institutions honored this important meeting with their presence.

The meeting was organized in two formats:

- Plenary presentations.

- Brainstorming in plenary 
To stimulate discussion, key actors presented an overview on adolescent/youth SRH:

- Follow-up of recommendations of the June 2015 workshop (Population Council)

- Assessment of SRH education in the formal education system (Division du Contrôle Médical Scolaire DCMS)

- Adolescent/youth RH service provision in the health system DSRSE)

- Role of the civil society in improving adolescent/youth SRH (Association Sénégalaise pour le Bien-Etre Familial - ASBEF)

Afterward, brainstorming allowed discussion on the following topics:

- How do we improve the legal and regulatory environment to better address adolescent/youth SRH issues?

- What strategies should be adopted to make user-friendly services available to adolescent/youth?

- What challenges, issues and prospects for sexual and reproductive education exist in schools?

The main resolutions/actions from the discussions are summarized below, by topic:

Revision of the laws on RH/FP and abortion:

- Planning of a meeting between the Advocacy Committee for Access to Safe Abortion (aka the "Taskforce") and the Health Commission of the National Assembly;

- Involvement of other Commissions of the National Assembly at this meeting with the Taskforce;

- Identification of the main pockets of resistance to the adoption of the law as part of the advocacy and communication activities conducted by the parliamentarians with the support of the Taskforce;

- Capacity strengthening of parliamentarians on communication about adolescent/youth unwanted pregnancies;

- Involvement of men, especially by replicating the "Bajenu Gox" initiative through the "Nidiayu Gox" initiative to involve them as community agents for advocacy purposes;

- Involvement of civil society as they can play a key role in addressing resistance at the community and religious levels;

- Implementation of awareness raising activities in communities in order to gain support for these law revisions. Parliamentarians who are always in touch with the people could play a key role in these awareness raising activities;

- Dissemination of the RH law: Parliamentarians indicated interest in supporting the dissemination of this law to communities;

- Awareness raising among magistrates and judges to enable better application of the laws;

- Focus on Sport and Cultural Associations (ASC) for events in neighborhoods to disseminate the laws to contribute to a sense of ownership of them; 


\section{Reproductive health education in schools:}

- Reflection on the need to give reproductive health education to children to prepare them for a healthy life. Children should not be considered only as passive targets, but as potential change agents.

- Introduction of reproductive health education beginning with primary school, adapted to student needs and capacity for comprehension.

- Creation of a system to monitor unwanted pregnancies in schools both at national and regional levels;

- Recruitment of social workers in schools to better address the needs of adolescent/youth.

- Awareness raising of parents to prepare them to discuss these issues within the family.

- Inclusion of the specific needs of adolescent/youth with disabilities, especially those who are blind and those who are deaf-mute.

- Inclusion of emerging issues in the revision process of training curricula through the Assistance Project to Curricula Revision (PARC) being implemented by the Ministry of National Education (MEN);

- Involvement of students' parents' associations in the design and implementation of SRH education programs.

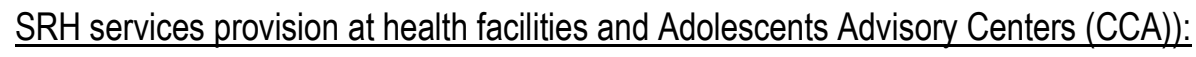

- Implementation of measures to accompany CCAs in better addressing the needs of adolescent/youth.

- Revitalization of the network.

- Capacity strengthening of stakeholders.

- Ensuring that adolescent/youth space is appropriately equipped in all health facilities. 


\section{Introduction}

En juin 2015, la Direction de la Santé de la Reproduction et de la Survie de l'Enfant (DSRSE) du Ministère de la Santé et de l'Action Sociale (MSAS), le Population Council, et Partners in Population and Development Africa Regional Office (PPD ARO), avaient co-organisé un atelier de partage des résultats de l'étude "Comprendre les grossesses non désirées au Sénégal- Profil-pays". Cet atelier qui avait ciblé les parlementaires et acteurs clés de la société civile avait pour objectifs de :

- Informer les décideurs sur les défis actuels du programme de Santé de la Reproduction et Survie de l'Enfant (SR/SE) et les problèmes prioritaires.

- Susciter l'engagement des autorités à la prise de décision pour résoudre les questions prioritaires.

- Engager les autorités à un débat autour des grossesses non désirées chez les adolescentes/jeunes.

Un des thèmes émergents lors de cette journée avait porté sur la problématique des grossesses non désirées chez les adolescents/jeunes au Sénégal. Ce thème avait fait l'objet d'un panel qui a été animé par Dr. Awa Dia Thiam (alors présidente de la Commission Santé de l'Assemblée Nationale), Dr. Marie-Louise Corréa (Présidente de l'ASBEF, représentant la société civile) et le Professeur Cheikh Tidiane Cissé (représentant l'Université Cheikh Anta Diop).

\section{Evidences de recherches et évaluations}

Les adolescents/jeunes, 10 - 24 ans, représentent $31 \%^{1}$ de la population du Sénégal. Au regard de leur poids démographique, répondre à leurs besoins de santé sexuelle et reproductive (SSR) constitue non seulement une priorité de santé publique mais contribue aussi à l'atteinte des objectifs de développement du pays, notamment ceux du Plan Sénégal Emergent (PSE).

Les adolescents/jeunes sont confrontés à la tentation et aux défis de la sexualité précoce. Ils peuvent adopter des comportements à risque, tels que les rapports sexuels non protégés qui les exposent aux risques de grossesses non désirées et aux Infections Sexuellement transmissibles (IST) y compris le VIH/Sida. Une étude de Guttmacher Institute (Guttmacher, 2004) réalisée dans 4 pays d'Afrique subsaharienne indique que les adolescentes ont tendance à avoir des relations sexuelles plus jeunes que les adolescents. Elles sont ainsi exposées plus tôt et plus longtemps aux risques de grossesses non désirées (GND) et d'IST.

Des évaluations récentes de programmes ciblant les adolescents/jeunes ont permis d'identifier des interventions susceptibles d'améliorer leur santé sexuelle et reproductive. Les principaux enseignements de ces évaluations sont :

Au niveau éducatif :

- Une approche orientée uniquement sur l'abstinence avant le mariage ne suffit pas pour promouvoir des comportements à moindre risque. II importe d'adopter des curricula qui proposent des informations intégrées et précises sur la SSR.

- II importe de cibler les très jeunes adolescents car beaucoup quittent l'école avant d'atteindre la classe à partir de laquelle l'éducation sexuelle est actuellement dispensée. Les programmes qui débutent avant la fin de l'école primaire augmente les chances de toucher les jeunes avant qu'ils ne quittent l'école et qu'ils ne débutent leur vie sexuelle. 
- Pour augmenter efficacement l'impact des programmes d'éducation sexuelle, il est indispensable que les professeurs bénéficient d'une formation adaptée sur les sujets liés à l'éducation sexuelle et sur les méthodes participatives d'apprentissage.

- II faut aider les adolescents à rester à l'école. Même s'ils ne reçoivent pas d'éducation sexuelle à l'école, les adolescents scolarisés sont moins sujets à avoir des relations sexuelles que leurs pairs non scolarisés.

Au niveau sanitaire:

- Il est important d'assurer la disponibilité d'une gamme variée de méthodes contraceptives, y compris le préservatif masculin et la contraception d'urgence, et de faciliter l'accès en rendant les produits disponibles non seulement dans les centres de santé mais aussi dans les boutiques, les pharmacies et les lieux où les jeunes travaillent ou socialisent.

- Les adolescents/jeunes doivent recevoir une information de base sur les services disponibles et les lieux où ils peuvent les obtenir. De plus, les prestataires de santé doivent utiliser chaque occasion de rencontre avec les adolescents/jeunes pour aborder les questions liées à leurs besoins en SSR.

- Les prestataires de santé doivent être formés pour fournir des informations et services aux adolescents/jeunes sans les stigmatiser. Cela peut aider à mettre en place des services conviviaux.

\section{Recommandations de l'atelier de juin 2015}

L'atelier de juin 2015 a permis de dégager des pistes d'interventions pour contribuer à mieux adresser les défis qui se posent à l'amélioration de la SSR des adolescents/jeunes. Les principales recommandations sont résumées cidessous :

\section{Au plan législatif :}

- Réviser la législation notamment en ce qui concerne l'avortement (article 305 du Code de procédure pénale) qui est trop restrictive et favorise l'avortement clandestin.

- Elaborer une loi plus répressive pour les cas de viol, notamment sur les mineurs/adolescents en vue de dissuader les auteurs.

- Renforcer la communication pour la diffusion du contenu de la loi pour une appropriation par les différents acteurs et la communauté.

- Mener des activités de plaidoyer auprès des parlementaires pour assurer la révision des lois et règlements pour une meilleure protection de la santé et des droits des adolescents/jeunes.

Au niveau du renforcement des capacités de prise en charge des besoins en SSR des adolescents/jeunes:

- Renforcer les capacités des adolescents/jeunes en révisant les curricula pour y inclure les aspects en rapport avec la sexualité en général, celle des adolescents/jeunes en particulier.

- Renforcer la communication pour rendre la communauté plus réceptive et tolérante aux messages destinés aux adolescents/jeunes et favoriser son adhésion.

- Promouvoir l'aménagement d'espaces d'écoute, d'informations/conseils et d'orientation destinés aux adolescents/jeunes dans chaque structure sanitaire.

- Renforcer l'approche multidisciplinaire et multisectorielle dans la prise en charge des problèmes des adolescents/jeunes.

- Mobiliser les ressources nécessaires pour le financement des activités du Plan Stratégique de Santé Sexuelle et de la Reproduction des Adolescent(e)s/Jeunes (SRAJ).

- Mettre en place un groupe de travail chargé du suivi de la mise en œuvre des recommandations issues de l'atelier. 


\section{Objectifs de l'atelier de juin 2016}

\section{Objectif général :}

Faire le point sur la mise en œuvre des recommandations de l'atelier de juin 2015 et engager les participants vers la mise en œuvre de stratégies pour contribuer à l'amélioration de la santé sexuelle et seproductive (SSR) des adolescents/jeunes.

\section{Objectifs spécifiques}

- Faire le point sur la mise en œuvre des recommandations de la rencontre de juin 2015.

- S'informer de la situation de la SSR dans le système éducatif et sanitaire ainsi que du rôle de la société civile.

- Réfléchir à l'amélioration des services de SSR et la problématique de l'éducation à la santé sexuelle.

- Formuler des recommandations et développer un plan d'action pour leur mise en œuvre.

\section{Méthodologie}

La rencontre s'est déroulée sous deux formats :

- Présentations en plénière.

- Brainstorming en plénière

\section{Déroulement de l'atelier}

Un total de 35 participants, dont 21 femmes et 14 hommes, ont assisté à la rencontre. Neuf (09) parlementaires, un représentant du Conseil Economique, Social et Environnemental (CESE), et des représentants de la société civile et des institutions partenaires ont rehaussé de leur présence cette importante rencontre.

\section{Cérémonie d'ouverture}

La cérémonie a été présidée par le Dr Pape Amadou Diack, Directeur Général de la Santé (DGS), représentant Madame le Ministre de la Santé et de l'Action Sociale, en compagnie de l'Honorable Député Aimé Assine, Président de la Commission Santé de l'Assemblée Nationale, du Dr. Nafissatou Diop, Directrice-Pays du Population Council, et de Mr. Patrick Mugirwa, Représentant de PPD ARO. Les représentants des institutions suivantes ont prononcé une allocution :

- Population Council $(P C)$ : le Dr. Nafissatou Diop, après avoir remercié les participants pour leur présence qui manifeste de l'intérêt accordé au sujet, est revenue sur l'historique de la rencontre qui est un prolongement de l'atelier de juin 2015. Dr. Diop s'est ensuite appesantie sur l'ampleur du phénomène des grossesses non désirées, sur leurs conséquences au plan démographique, sanitaire et social ainsi que sur leurs causes souvent liées aux besoins non satisfaits (BNS) en planification familiale (PF). Par ailleurs, elle a souligné l'intérêt de mettre à la disposition des décideurs et acteurs clés des informations fiables pour leur permettre de prendre des décisions basées sur des évidences. Elle a aussi rappelé l'importance de la mobilisation de tous les acteurs pour adresser ce fléau. 
- Commission Santé de l'Assemblée Nationale : l'Honorable Député Aimé Assine a salué l'initiative du Ministère de la Santé et de l'Action Sociale et de ses partenaires (Population Council et PPD ARO) de les associer à l'organisation de cette rencontre qui traite d'un sujet d'actualité aussi important. Le Président a rappelé la mission de l'Assemblée Nationale d'accompagner les pouvoirs publics dans la définition et la mise en œuvre des politiques visant à garantir à chaque citoyen un bien-être social et économique équitable et durable. II est aussi revenu sur le caractère sensible du sujet et de la cible. Accorder une attention aux adolescents/jeunes a des implications sur l'équilibre social et économique de notre société, d'où, selon lui, l'urgence d'agir et de répondre à leurs besoins dans le contexte d'un Sénégal émergent. A cet effet, il a rappelé la responsabilité de l'Assemblée Nationale et renouvelé l'engagement de son institution à relever les défis qui se posent à la promotion de la santé reproductive des adolescents/jeunes.

- Ministère de la Santé et de l'Action Sociale : le DGS a rappelé la volonté des pouvoirs publics qui se traduit par l'adoption du Plan Sénégal Emergent (PSE) en droite ligne avec les Objectifs de Développement Durable (ODD), notamment les objectifs 3 et 5 . Par la suite, il est revenu sur l'ampleur des BNS en PF parmi les adolescents/jeunes, dont résulteraient les GND et leur impact sur la mortalité maternelle et infantile. Le DGS a aussi souligné que le faible accès des adolescents/jeunes aux services de santé contribue à l'ampleur de ces GND et à leurs conséquences. II a suggéré des pistes d'interventions telles que l'amélioration de l'accès à l'information, la prise en compte des facteurs socioculturelles, l'amélioration du cadre juridique, une meilleure coordination des interventions et une mobilisation accrue des ressources. Il a conclu en remerciant les parlementaires et l'ensemble des acteurs pour leur collaboration avec le MSAS.

\section{Présentations en plénière}

A la suite de la cérémonie d'ouverture, les présentations suivantes ont été partagées avec les participants:

- Suivi des recommandations de l'atelier du 04 juin 2015, par Mr. Babacar Mané, Consultant Population Council.

Mr. Babacar Mané, consultant du Population Council, facilitateur de l'atelier, a procédé au rappel des recommandations formulées lors de l'atelier de juin 2015 et à leur état d'exécution. Le tableau ci-dessous fait le point sur la mise en œuvre de ces recommandations.

$\odot$ Concernant la législation

\begin{tabular}{|c|c|c|}
\hline Recommandations & Institutions impliquées & Statut d'exécution \\
\hline $\begin{array}{l}\text { Nécessité de réviser la législation } \\
\text { notamment en ce qui concerne } \\
\text { l'avortement (article } 305 \text { du code de } \\
\text { procédure pénale) qui est trop } \\
\text { restrictive et favorise l'avortement } \\
\text { clandestin }\end{array}$ & $\begin{array}{l}\text { MSAS (DSRSE, Cabinet, Inspection chargée } \\
\text { des aspects juridiques) } \\
\text { Assemblée Nationale (Commission chargée } \\
\text { des lois ; Commission Santé) } \\
\text { Ministère de la Justice } \\
\text { Ministère de la Famille } \\
\text { Société Civile } \\
\text { Taskforce travaillant sur un plan d'action pour } \\
\text { la révision de la loi sur l'avortement (ex: } \\
\text { assouplissement de la loi pour les cas de } \\
\text { viol/inceste) }\end{array}$ & $\begin{array}{l}\text { - Statut quo } \\
\text { - Activités de plaidoyer de } \\
\text { la Taskforce pour } \\
\text { l'assouplissement de la } \\
\text { loi }\end{array}$ \\
\hline
\end{tabular}




\begin{tabular}{|c|c|c|}
\hline Recommandations & Institutions impliquées & Statut d'exécution \\
\hline $\begin{array}{l}\text { Nécessité d'une loi plus répressive } \\
\text { pour les cas de viol, notamment sur } \\
\text { les mineurs/adolescents pour } \\
\text { dissuader les auteurs }\end{array}$ & $\begin{array}{l}\text { MSAS (DSRSE, Cabinet, Inspection chargée } \\
\text { des aspects juridiques) } \\
\text { Assemblée Nationale (Commission chargée } \\
\text { des lois ; Commission Santé) } \\
\text { Ministère de la Justice } \\
\text { Société Civile }\end{array}$ & $\begin{array}{l}\text { - Codifié comme délit par } \\
\text { l'article } 320 \text { du code pénal } \\
\text { qui lui consacre une } \\
\text { définition plus en } \\
\text { englobante (inclusion des } \\
\text { agressions de quelque } \\
\text { nature que ce soit } \\
\text { - } 5 \text { à } 10 \text { ans de prison } \\
\text { - Problème d'application de la } \\
\text { loi qui ressort du pouvoir } \\
\text { discrétionnaire du juge } \\
\text { (circonstances du viol, pas } \\
\text { de peine cumulative) }\end{array}$ \\
\hline $\begin{array}{l}\text { Nécessité de s'approprier les } \\
\text { lois par les différents acteurs et } \\
\text { la communauté, ce qui suppose } \\
\text { un renforcement de la } \\
\text { communication pour la diffusion } \\
\text { du contenu de la loi }\end{array}$ & $\begin{array}{l}\text { MSAS (DSRSE) } \\
\text { Commission Santé Assemblée }\end{array}$ & $\begin{array}{l}\text { - Loi SR adoptée en } 2005 \\
\text { tarde encore à être effective } \\
\text { - La vulgarisation des lois } \\
\text { n'est pas encore effective }\end{array}$ \\
\hline $\begin{array}{l}\text { Nécessité de mener des } \\
\text { activités de plaidoyer auprès } \\
\text { des parlementaires pour assurer } \\
\text { la révision des lois et } \\
\text { règlements qui ne favorisent } \\
\text { pas une bonne protection des } \\
\text { adolescents/jeunes }\end{array}$ & $\begin{array}{l}\text { MSAS (DSRSE) } \\
\text { Ministère de la Jeunesse } \\
\text { Partenaires Techniques } \\
\text { Taskforce }\end{array}$ & $\begin{array}{l}\text { - Non effective } \\
\text { - Prévue dans le Plan de } \\
\text { communication/plaidoyer du } \\
\text { plan stratégique SRAJ- } \\
\text { DSRSE }\end{array}$ \\
\hline
\end{tabular}

$\odot$ Concernant le renforcement des capacités et la prise en charge

\begin{tabular}{|c|c|c|}
\hline Recommandations & \begin{tabular}{|l|} 
Institutions impliquées \\
\end{tabular} & Statut d'exécution \\
\hline $\begin{array}{l}\text { Nécessité de renforcer les capacités } \\
\text { des adolescents/jeunes en révisant } \\
\text { les curricula pour y inclure les aspects } \\
\text { en rapport avec la sexualité en } \\
\text { général, celle des adolescents en } \\
\text { particulier }\end{array}$ & $\begin{array}{l}\text { MSAS (DSRSE-Division SRAJ, SNEIPS) } \\
\text { Ministère de la Jeunesse (PPJ) } \\
\text { Ministère de l'Education Nationale (DCMS) } \\
\text { Groupe pour l'Education et l'Enseignement } \\
\text { de la Population (GEEP) } \\
\text { ASBEF }\end{array}$ & $\begin{array}{l}\text { - Développement de curricula } \\
\text { sur la SRAJ au niveau des } \\
\text { systèmes éducatif et de } \\
\text { santé et en milieu extra- } \\
\text { scolaire (PPJ, ASBEF) } \\
\text { - Processus de révision des } \\
\text { curricula au niveau du } \\
\text { système éducatif } \\
\text { - Formation de pairs } \\
\text { éducateurs } \\
\text { - Processus d'harmonisation } \\
\text { des curricula de formation } \\
\text { enclenché }\end{array}$ \\
\hline $\begin{array}{l}\text { Nécessité de renforcer les capacités } \\
\text { de la communauté pour la rendre plus } \\
\text { tolérante aux messages destinés aux } \\
\text { adolescents et favoriser son } \\
\text { adhésion }\end{array}$ & $\begin{array}{l}\text { MSAS (DSRSE, SNEIPS) } \\
\text { Ministère de la Jeunesse (PPJ) } \\
\text { Société Civile } \\
\text { Assemblée Nationale (Commission Santé et } \\
\text { Commission chargée des lois) }\end{array}$ & $\begin{array}{l}\text { - La DSRSE a engagé un } \\
\text { processus de } \\
\text { développement d'un plan de } \\
\text { communication pour la } \\
\text { promotion de la SRAJ en } \\
\text { direction de la communauté }\end{array}$ \\
\hline
\end{tabular}




\begin{tabular}{|c|c|c|}
\hline Recommandations & Institutions impliquées & Statut d'exécution \\
\hline $\begin{array}{l}\text { Nécessité de renforcer l'accès aux } \\
\text { structures d'écoute et de conseils } \\
\text { pour adolescents/jeunes, tout en } \\
\text { veillant à leur adaptabilité et } \\
\text { fonctionnalité (aménagement, } \\
\text { horaires...). }\end{array}$ & MSAS (DSRSE, SNEIPS) & $\begin{array}{l}\text { - Mise en place d'espaces } \\
\text { - } \text { - Reunes } \\
\text { téléconsutement de } \\
\text { - Mise à disposition d'un } \\
\text { numéro vert par le SNEIPS } \\
\text { - Mise en place de Centres } \\
\text { Conseils Adolescents par le } \\
\text { PPJ } \\
\text { - Mise en place de clubs EVP } \\
\text { au niveau des } \\
\text { établissements scolaires }\end{array}$ \\
\hline $\begin{array}{l}\text { Nécessité d'aménager des espaces } \\
\text { de prise en charge des } \\
\text { adolescents/jeunes dans chaque } \\
\text { structure sanitaire. }\end{array}$ & $\begin{array}{l}\text { MSAS (DSRSE) } \\
\text { Régions Médicales/Districts Sanitaires } \\
\text { Partenaires Techniques et Financiers }\end{array}$ & - En cours \\
\hline $\begin{array}{l}\text { Nécessité d'adopter une approche } \\
\text { multidisciplinaire et multisectorielle } \\
\text { dans la prise en charge des } \\
\text { problèmes des adolescents/ } \\
\text { jeunes et de proposer un forum pour } \\
\text { l'élaboration d'un plan stratégique } \\
\text { harmonisé. }\end{array}$ & MSAS (DSRSE) & $\begin{array}{l}\text { - Mise en place d'un cadre de } \\
\text { concertation autour de la } \\
\text { DSRSE } \\
\text { - Mise en place d'une } \\
\text { coalition des acteurs de la } \\
\text { société civile autour de la } \\
\text { SRAJ }\end{array}$ \\
\hline
\end{tabular}

$\odot$ Concernant le financement

\begin{tabular}{|l|l|l|}
\hline Recommandations & Institutions impliquées & Statut d'exécution \\
\hline $\begin{array}{l}\text { Nécessité de mobiliser des } \\
\text { ressources pour le financement d'un } \\
\text { plan stratégique consensuel et } \\
\text { réaliste. }\end{array}$ & $\begin{array}{l}\text { Assemblée Nationale (Commission Finances } \\
\text { et Commission Santé) }\end{array}$ & - Financement parcellaire \\
\hline
\end{tabular}

- Bilan de l'éducation à la santé sexuelle et reproductive dans le système éducatif formel : bilan, défis et perspectives, par Mr. Mamadou Ndiaye. Division du Contrôle Médical Scolaire (DCMS) du Ministère de l'Education Nationale (MEN).

Dans son intervention, le représentant de la DCMS, Mr. Mamadou Ndiaye, est revenu sur les principaux acquis, ainsi que sur les défis liés à la SSR au niveau des écoles. II a commencé par rappeler le contexte de la SRAJ marqué par une forte exposition des adolescents à la sexualité et aux grossesses précoces souvent non planifiées, aux mariages précoces. II a ensuite souligné le poids démographique important des adolescents dans la population scolaire (près de 3 millions - MEN, 2014-2015). Mr Ndiaye a ensuite rappelé l'engagement des autorités éducatives, le cadre de référence qui a motivé les interventions en matière d'éducation sexuelle et reproductive dans le système éducatif avant de appesantir sur les principaux problèmes de SSR au niveau de l'école (ex: GND, mariages précoces, violences basées sur le genre, problèmes liées à la gestion des menstrues, usage de substances nocives). II a fini en présentant les réponses apportées par la DCMS, notamment l'intégration de la SR dans l'enseignement ; la note circulaire de 2007 sur les grossesses d'élèves ; la formation/sensibilisation des élèves, professeurs et parents d'élèves ; et la mise en place de services de SR dans les établissements scolaires). 


\section{- Offre de services SRAJ en milieu extra-scolaire : Expérience du Projet Promotion des Jeunes}

Une présentation était prévue sur le contexte extra-scolaire, mais n'a pu être faite.

- Offre de services de SRAJ dans le système de santé : bilan, défis et perspectives, par Dr. MarieJésus Buabey, DSRSE

Dans son introduction, le Dr. Marie-Jésus Buabey, représentant la DSRSE, a souligné le poids démographique et les indicateurs SR des adolescents/jeunes. Ensuite, elle a partagé la vision, le but, les objectifs et les orientations stratégiques du Plan Stratégique SRAJ qui sont basées sur les directives de l'OMS. Ces orientations stratégiques reposent sur la communication, le plaidoyer, le renforcement des capacités, l'instauration d'un environnement favorable à la promotion de la SRAJ, le développement de l'offre de service selon les standards. Le Dr. Buabey est revenue sur le bilan des interventions en matière de SRAJ en s'appuyant sur les données actualisées issues des Enquêtes Démographiques et de Santé (EDS) et des données de supervisions de routine réalisées par le MSAS. Ces interventions portent sur l'élaboration des standards, de curricula et de supports promotionnels, la formation des prestataires et des pairs-éducateurs en SRAJ, la formation des formateurs en éducation à la santé sexuelle, l'appui à l'équipement d'espaces ados/jeunes aménagés dans les structures de santé, la mise en place d'un cadre de concertation multisectoriel des acteurs intervenant dans la SRAJ. En conclusion, elle a rappelé les défis qui se posent à la mise en œuvre du Plan Stratégique, notamment l'accès des jeunes aux services et à l'information en matière de SR, l'implication des parents et de la communauté, la coordination des interventions des acteurs pour une plus grande synergie et la mobilisation des ressources pour financer l'exécution du Plan.

- Rôle de la société civile dans l'amélioration de la santé sexuelle et reproductive des adolescents/jeunes : Expérience de l'Association Sénégalaise pour le Bien-être Familial, par Pape Momar Mbaye, ASBEF.

Le représentant de l'ASBEF, Mr. Pape Momar Mbaye, a rappelé les axes stratégiques d'interventions de l'ASBEF en matière de promotion de la SSR des adolescents/jeunes. Ces axes reposent sur : l'éducation à la SR, l'offre de services cliniques en matière de SSR et le plaidoyer/réseautage. En matière d'éducation à la SR, les interventions portent sur: le développement de manuels, la formation des formateurs et pairs éducateurs, la formation/sensibilisation des jeunes/parents et enseignants, le ciblage des adolescents/jeunes en situation de handicap (sourds muets, non-voyants) avec l'utilisation d'approches de communication adaptées, l'utilisation des NTICs... Dans le domaine de l'offre, les principales interventions portent sur : la formation des prestataires en offre de services conviviaux, l'aménagement d'espaces adolescents/jeunes, la définition d'horaires et de jours pour l'offre de services aux adolescents/jeunes, la mise en place de tickets sociaux ou la gratuité des services pour les adolescents/jeunes... Dans le domaine du plaidoyer, les principales actions menées portent sur la mise en place d'une coalition pour la SRAJ, la formation des adolescents/jeunes en leadership, plaidoyer auprès des autorités publiques et religieuses, et le partenariat avec d'autres acteurs. Mr. Mbaye a aussi partagé quelques statistiques de services offerts aux adolescent/jeunes par l'ASBEF (ex : 1988084 services de SR durant la période 2011-2015). En conclusion, il a évoqué les acquis et défis, et proposer des recommandations pour la promotion de la SSR des adolescents/jeunes. 


\section{Discussions sur les présentations}

A l'issue des présentations, des questions de clarification ont été soulevées et des contributions apportées. Les principaux points de discussion ont porté sur :

\section{A niveau législatif:}

- La nécessité de la révision de la loi sur l'avortement en raison de son caractère trop restrictif. Cet avis, qui a été notamment émis par les parlementaires, a été motivé par une recrudescence des cas de viol et d'inceste et des GND de plus en plus souvent rapportés par les médias. Les parlementaires ont manifesté une volonté de mener un plaidoyer auprès de leurs pairs et auprès des décideurs pour un assouplissement de cette loi. Toutefois, les députés souhaiteraient bénéficier d'un renforcement de capacité en communication et en plaidoyer sur le sujet pour leur permettre de mieux sensibiliser les décideurs et communautés et faciliter la révision de la loi. En outre, les parlementaires ont réaffirmé leur volonté de porter le plaidoyer au sein de l'hémicycle. Toutefois, ils jugent que des actions concomitantes de sensibilisation devraient être menées, notamment par la société civile, pour adresser la résistance des religieux et des communautés.

- L'adoption du code de l'enfant: les parlementaires ont recommandé que ce code soit soumis à l'Assemblée Nationale pour son adoption pour assurer une protection effective de cette cible vulnérable.

Au niveau de la famille :

- L'implication des parents : le ciblage des parents dans les interventions demeure capital pour permettre à l'unité familiale de jouer un rôle dans l'éducation sexuelle et la prévention des GND. En effet, il a été constaté que les parents, pour des raisons diverses, ne jouent plus suffisamment ce rôle d'éducateur. Le renforcement de leurs capacités en communication sur la sexualité devrait être intégré dans les programmes d'intervention.

\section{Au niveau des groupes vulnérables}

- La prise en compte des besoins des handicapés : du fait de la spécificité de cette cible, des approches de communication adaptées devraient être utilisées pour mieux adresser leurs besoins, notamment ceux des malentendants ou non-voyants. Par exemple, le langage des signes (pour les malentendants), le braille (pour les non-voyants), ou l'utilisation des SMS pourraient être des alternatives à explorer.

Au niveau des systèmes scolaire et sanitaire :

- La nécessité de l'harmonisation des curricula au niveau du système scolaire : pour une meilleure harmonisation des messages destinés aux adolescents/jeunes, il importe de revoir les curricula de formation qui sont variés. La mise en place par le MEN d'un Projet d'Appui à la Révision des Curricula (PARC) s'inscrit dans cette perspective. Le PARC devrait être un réceptacle de l'ensemble des curricula disponibles pour une information harmonisée. La coalition sur la SRAJ créée par la société civile pourrait aussi jouer un rôle dans cette direction.

- Les directives relatives à l'exclusion des filles enceintes de l'école sont discriminatoires et devraient être revues. Les filles sont exclues de l'école alors que les garçons ne sont nullement inquiétés, même s'ils sont les auteurs des grossesses.

- La nécessité d'ériger la DCMS en Direction : au regard du caractère sensible des questions d'éducation sexuelle et reproductive, il a été suggéré d'ériger la DCMS de Division en Direction.

- L'état d'intégration des stratégies avancées expérimentées par l'ASBEF au niveau des écoles. 
- La synergie entre l'école et les structures de santé : une approche synergique devrait être impulsée entre l'école et les structures de santé pour assurer une prise en charge complète des besoins des adolescents/jeunes. L'initiative "centres de santé amis des jeunes" pourra être consolidée et mise à l'échelle.

\section{Au niveau organisationnel}

- La nécessité de promouvoir une approche multisectorielle: la prise en charge des besoins des adolescents/jeunes nécessite une démarche multisectorielle au regard de la diversité des acteurs interpellés par le sujet. Le cadre de concertation mis en place autour de la DSRSE et la coalition SRAJ de la société civile pourraient faciliter cette approche.

- La disponibilité des données sur la SRAJ : la préoccupation d'avoir des données actualisées sur les GND a été évoquée. Par ailleurs, l'intérêt de fixer des objectifs et de mettre en place des indicateurs de mesure des effets des interventions a été abordé.

- L'approche "Droits Humains" comme stratégie de communication sur la SRAJ : la communication sur la SRAJ constitue une difficulté majeure. On assiste ainsi à une déconstruction de la communication du fait des facteurs bloquants et de la résistance des religieux, notamment. Cette situation interpelle sur le discours à tenir. L'approche « Droits Humains » des adolescents/jeunes pourrait être une alternative.

Au niveau de la mobilisation des ressources:

- La nécessité de mobiliser les ressources pour la mise en œuvre du plan de communication sur la SRAJ développé par la DSRSE.

- La mobilisation des ressources par les parlementaires: au regard de la pertinence du programme SR en général, de celui de la SRAJ en particulier, les députés ont réaffirmé leur engagement pour faire le plaidoyer pour une mobilisation accrue des ressources.

- La mobilisation des ressources pour les pairs éducateurs et le renforcement de leurs capacités : ceux-ci n'ont souvent pas à leur disposition les ressources nécessaires pour mener à bien leur mission. D'où la nécessité de mener des actions de plaidoyer pour mettre à leur disposition les ressources adéquates. De même, la mise à jour périodique des connaissances des pairs éducateurs à travers la formation devra être envisagée.

A la suite des questions/commentaires, quelques éléments de clarification ont été apportés par les présentateurs:

- L'érection de la DCMS en Direction est à l'ordre du jour au MEN. Le processus est en cours.

- Concernant la mise à jour des données au niveau du système éducatif, la DCMS a déjà mis en place un dispositif pour assurer une collecte régulière des données.

- La mobilisation des ressources pour la mise en œuvre du Plan de Communication sur la SRAJ : le besoin de mobilisation des ressources demeure encore pour ce Plan tout autant que pour le Plan Stratégique SRAJ global. D'où un appel au plaidoyer auprès des parlementaires. 


\section{Brainstorming en plénière}

Sur proposition des organisateurs, les travaux de groupe initialement prévus ont été changés par consensus en brainstorming en plénière sur les 3 thématiques suivantes :

- Comment améliorer l'environnement juridique et législatif pour mieux adresser la problématique de la SSR des adolescents/jeunes?

- Quelles stratégies adopter pour des services conviviaux aux adolescents/jeunes ?

- Quels sont les défis, enjeux et perspectives de l'éducation sexuelle et reproductive à l'école ?

\section{$\underline{\text { Révision de la loi sur l'avortement : }}$}

En préambule, une mise à jour sur les activités de la Taskforce a été faite par un de ces membres. Les activités de ses 3 groupes (Communauté, Parlementaires et Médias) ont été résumées pour donner aux participants un aperçu des actions entreprises.

Les principales actions identifiées à l'issue du brainstorming sont :

- Proposition d'une rencontre entre la Taskforce et la Commission Santé de l'Assemblée Nationale.

- Implication des autres commissions de l'Assemblée Nationale lors de cette rencontre avec la Taskforce.

- Identification des poches de résistance à l'adoption de la loi dans le cadre des activités de plaidoyer et communication qui seront menées par les parlementaires avec l'appui de la Taskforce.

- Renforcement des capacités des parlementaires en communication sur le sujet des GND des adolescents/jeunes.

- Implication des hommes, notamment en répliquant l'initiative "Bajenu Gox" à travers "I'initiative "Nidiayu Gox" permettant de les utiliser comme agents communautaires dans le plaidoyer.

- Implication de la société civile qui peut jouer un rôle déterminant pour adresser les résistances au niveau communautaire et des religieux.

- Déroulement d'activités de sensibilisation auprès des communautés pour qu'elles s'approprient les lois qui seront votées. Les parlementaires qui sont en contact permanent avec les populations pourraient jouer un rôle déterminant dans ces activités de sensibilisation.

- Vulgarisation de la loi SR : les parlementaires ont manifesté un intérêt pour appuyer la dissémination de cette loi auprès des communautés.

- Sensibilisation des magistrats et des juges pour une meilleure application des lois

- Ciblage des ASC au niveau des quartiers pour des actions de vulgarisation des lois en vue de leur appropriation.

Education à la santé de la reproduction au niveau des écoles :

- Réflexion sur la nécessité de donner une éducation à la santé de la reproduction aux enfants pour les préparer à une vie saine. Les enfants ne doivent pas seulement être considérés comme des cibles passives mais comme pouvant être des acteurs de changement.

- Introduction de l'éducation à la santé de la reproduction dès l'élémentaire, adaptée aux besoins et niveaux de compréhension des élèves.

- Mise en place d'un observatoire pour le suivi des grossesses non désirées en milieu scolaire aussi bien au niveau national que régional. 
- Recrutement d'assistants sociaux au niveau des écoles pour mieux répondre aux besoins des adolescents/jeunes

- Sensibilisation des parents pour les préparer à aborder ces questions au sein de la famille.

- Prise en compte des adolescents/jeunes vivant avec un handicap, notamment les aveugles et les sourdsmuets.

- Inclusion des questions émergentes dans le processus de révision des curricula de formation à travers le PARC mis en place par le MEN.

- Implication des associations de parents d'élèves dans la conception et la mise en œuvre des programmes d'éducation sexuelle et reproductive.

Offre de services SRAJ au niveau des structures d'accueil (structure de santé et CCA):

- Mise en place de mesures d'accompagnement des CCA pour qu'ils puissent mieux répondre aux besoins des adolescents/jeunes.

- Redynamisation du réseau des CCA.

- Renforcement des capacités des acteurs intervenant dans la SRAJ.

- Systématisation d'espaces ados/jeunes dotés d'équipements adéquats dans les structures de santé. 


\section{Résumé des recommandations et actions à entreprendre}

\begin{tabular}{|c|c|c|c|}
\hline Recommandations & Actions à entreprendre & Institutions responsables & Date \\
\hline \multicolumn{4}{|l|}{ Législation } \\
\hline $\begin{array}{l}\text { Révision de la loi sur } \\
\text { l'avortement }\end{array}$ & 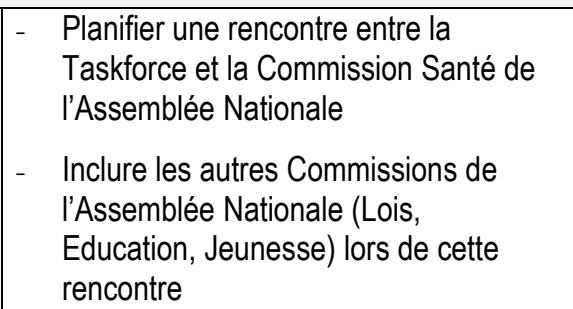 & $\begin{array}{l}\text { - Taskforce (Coordinatrice) } \\
\text { - Président Commission } \\
\text { Santé de l'Assemblée } \\
\text { Nationale }\end{array}$ & - Juillet-Août 2016 \\
\hline $\begin{array}{lr}\text { Renforcer les capacités } \\
\text { des parlementaires } & \text { en } \\
\text { communication } & \text { et } \\
\text { plaidoyer sur le sujet } & \end{array}$ & $\begin{array}{ll}\text { - } & \text { La DSRSE et la Taskforce doivent faire } \\
& \text { une proposition technique } \\
\text { - } & \text { Programmer des sessions de } \\
& \text { formation }\end{array}$ & $\begin{array}{l}\text { - DSRSE } \\
\text { - Taskforce }\end{array}$ & $-A D$ \\
\hline $\begin{array}{l}\text { Réviser la loi SR en y } \\
\text { incluant les questions } \\
\text { émergentes }\end{array}$ & $\begin{array}{ll}- & \text { La DSRSE doit se rapprocher de } \\
\text { l'Assemblée Nationale pour définir un } \\
\text { plan de travail } \\
\text { - } & \text { Programmer des ateliers de révision } \\
& \text { de la loi SR }\end{array}$ & - DSRSE & $-A D$ \\
\hline $\begin{array}{l}\text { Réviser et vulgariser la loi } \\
\text { SR }\end{array}$ & $\begin{array}{ll}- & \text { Mettre en place un plan de travail } \\
\text { - } & \text { Programmer une caravane }\end{array}$ & $\begin{array}{l}\text { - DSRSE } \\
\text { - Parlementaires }\end{array}$ & $-A D$ \\
\hline $\begin{array}{l}\text { Cibler les magistrats et les } \\
\text { juges }\end{array}$ & $\begin{array}{ll}\text { - } & \text { Mener des actions de } \\
& \text { sensibilisation/plaidoyer }\end{array}$ & - Taskforce & $-A D$ \\
\hline $\begin{array}{lr}\text { Sensibiliser } & \text { les } \\
\text { communautés sur la loi SR } \\
\text { et sur la loi sur l'avortement }\end{array}$ & - $\quad$ Développer un plan d'actions & $\begin{array}{l}\text { - DSRSE } \\
\text { - Taskforce }\end{array}$ & $-A D$ \\
\hline \multicolumn{4}{|l|}{ Offre de services SR } \\
\hline $\begin{array}{l}\text { Généraliser les espaces } \\
\text { ados/jeunes et mettre en } \\
\text { place des mesures } \\
\text { d'accompagnement pour } \\
\text { les rendre opérationnels }\end{array}$ & $\begin{array}{ll}- & \text { Mobiliser les ressources } \\
- & \text { Mettre en place les infrastructures et } \\
& \text { équipement nécessaires }\end{array}$ & $\begin{array}{l}\text { - DSRSE } \\
\text { - Partenaires } \\
\text { - Collectivités locales }\end{array}$ & $-A D$ \\
\hline $\begin{array}{l}\text { Assurer une meilleure } \\
\text { synergie avec les CCA et } \\
\text { les écoles }\end{array}$ & 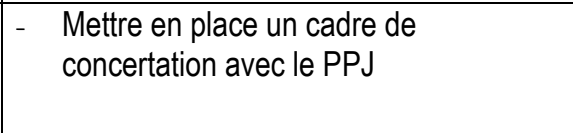 & $\begin{array}{l}\text { - DSRSE } \\
\text { - DCMS } \\
\text { - PPJ }\end{array}$ & $-A D$ \\
\hline $\begin{array}{lr}\text { Développer } & \text { une meilleure } \\
\text { synergie } & \text { entre les } \\
\text { structures } & \text { sanitaires } \\
\text { publiques et les CCA }\end{array}$ & $\begin{array}{l}\text { Mettre en place un système de } \\
\text { référence-contre-référence }\end{array}$ & $\begin{array}{l}\text { - DSRSE } \\
\text { - PPJ } \\
\text { - DCMS }\end{array}$ & $-A D$ \\
\hline $\begin{array}{l}\text { Améliorer l'accès des } \\
\text { adolescents/jeunes à } \\
\text { l'information de qualité et } \\
\text { aux services SRAJ }\end{array}$ & - Vulgariser le numéro vert du SNEIPS & - DSRSE/SNEIPS & $-A D$ \\
\hline
\end{tabular}

Education à la santé de la reproduction /prise en charge des besoins de SSR au niveau des écoles 


\begin{tabular}{|c|c|c|c|}
\hline Recommandations & Actions à entreprendre & Institutions responsables & Date \\
\hline $\begin{array}{l}\text { Inclure les questions } \\
\text { émergentes dans les } \\
\text { curricula de formation dans } \\
\text { les écoles }\end{array}$ & - Réviser les curricula & $\begin{array}{l}\text { - DCMS } \\
\text { - PARC }\end{array}$ & $-A D$ \\
\hline $\begin{array}{l}\text { Harmoniser les curricula } \\
\text { de formation }\end{array}$ & - $\quad$ Organiser des ateliers de concertation & - PARC & $-A D$ \\
\hline $\begin{array}{l}\text { Prendre en compte les } \\
\text { enfants de moins de cinq } \\
\text { (5) ans dans l'éducation à } \\
\text { la santé de la reproduction } \\
\text { dans le système éducatif }\end{array}$ & $\begin{array}{l}\text { - Intégrer l'éducation SR au niveau de la } \\
\text { case des tout-petits }\end{array}$ & - MEN/DCMS & $-A D$ \\
\hline $\begin{array}{l}\text { Assurer le suivi et } \\
\text { l'actualisation des données } \\
\text { sur les GND au niveau des } \\
\text { écoles }\end{array}$ & - $\quad$ Mettre en place un observatoire & - DCMS & $-A D$ \\
\hline \multicolumn{4}{|l|}{ Autres } \\
\hline $\begin{array}{l}\text { Sensibiliser les parents sur } \\
\text { la SRAJ }\end{array}$ & - Développer des plans de formation & $\begin{array}{l}\text { - DSRSE } \\
\text { - ASBEF } \\
\text { - DCMS } \\
\text { - PPJ }\end{array}$ & $-A D$ \\
\hline \multirow{2}{*}{$\begin{array}{l}\text { Assurer une meilleure } \\
\text { coordination } \\
\text { interventions en matière de } \\
\text { SRAJ }\end{array}$} & $\begin{array}{ll}\text { - } & \text { Procéder à une cartographie des } \\
\text { interventions sur la SRAJ }\end{array}$ & - DSRSE/Division SRAJ & $-A D$ \\
\hline & $\begin{array}{ll}\text { - } & \text { Redynamiser le cadre de concertation sur la } \\
\text { SRAJ mis en place au niveau de la DSRSE }\end{array}$ & - DSRSE/Division SRAJ & $-A D$ \\
\hline
\end{tabular}

$A D$ : A déterminer

\section{Divers}

Le représentant de PPD ARO a salué l'intérêt et l'engagement des partenaires sur le sujet, et les a informé de la tenue de la prochaine rencontre des membres de Commission Santé des Assemblées Nationales Africaines à Kampala du 28 juin au 2 juillet 2016. II a présenté les thèmes de cette rencontre et précisé que la Commission Santé de l'Assemblée Nationale du Sénégal a été invitée à cette rencontre. Un courrier a été adressé au Président de l'Assemblée Nationale sénégalaise. PPD ARO espère que les députés sénégalais pourront participer. 


\section{Annexes}
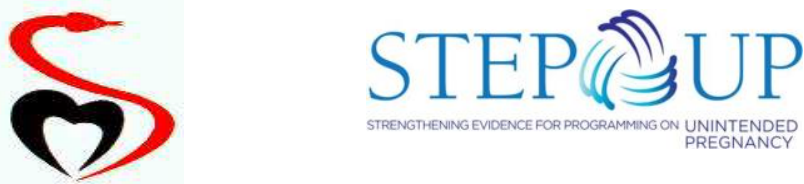

POPULATION COUNCIL

Ideas. Evidence. Impact.

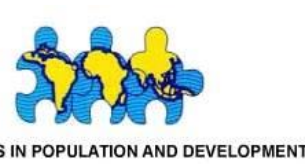

\section{Rencontre de partage sur la problématique des grossesses non désirées chez les adolescents/jeunes au Sénégal}

\section{Agenda}

\begin{tabular}{|c|c|c|}
\hline Horaires & Activités & Responsables/Présentateurs \\
\hline 08:30-09h00 & Accueil des participants & Population Council \\
\hline 09h-09h45 & $\begin{array}{l}\text { Cérémonie d'ouverture: } \\
\text { - Allocution du Population Council } \\
\text { - Allocution du Président de la Commission } \\
\text { Santé de l'Assemblée Nationale } \\
\text { - Discours d'ouverture du Ministère de la } \\
\quad \text { Santé et de l'Action Sociale (MSAS) }\end{array}$ & MSAS \\
\hline $09 \mathrm{~h} 45-10 \mathrm{~h} 00$ & $\begin{array}{l}\text { Présentation des objectifs et de l'agenda de } \\
\text { l'atelier }\end{array}$ & Population Council \\
\hline 10h00-10h15 & $\begin{array}{l}\text { Suivi des recommandations de l'atelier du } 04 \\
\text { Juin } 2015\end{array}$ & Population Council \\
\hline 10h15-10h45 & \multicolumn{2}{|l|}{ Pause-café - Photo de famille } \\
\hline \multirow[t]{4}{*}{$10 \mathrm{~h} 45-11 \mathrm{~h} 45$} & $\begin{array}{l}\text { Bilan de l'éducation à la santé sexuelle et } \\
\text { reproductive dans le système éducatif formel : } \\
\text { bilan, défis et perspectives }(15 \mathrm{mn})\end{array}$ & DCMS \\
\hline & $\begin{array}{l}\text { Offre de services SRAJ en milieu extra- } \\
\text { scolaire : Expérience du Projet Promotion des } \\
\text { Jeunes }(\mathrm{PPJ}(15 \mathrm{mn})\end{array}$ & PPJ \\
\hline & $\begin{array}{l}\text { Offre de services de SRAJ dans le système de } \\
\text { santé : bilan, défis et perspectives }(15 \mathrm{mn})\end{array}$ & DSRSE \\
\hline & $\begin{array}{l}\text { Rôle de la société civile dans l'amélioration de } \\
\text { la santé sexuelle et reproductive des } \\
\text { adolescents/jeunes : Expérience de } \\
\text { l'Association Sénégalaise de Bien-Etre } \\
\text { Familiale (ASBEF) }(15 \mathrm{mn})\end{array}$ & ASBEF \\
\hline 11h45-12h15 & Discussions & DSRSE \\
\hline 12h15-13h30 & $\begin{array}{l}\text { Travaux de groupe sur les thématiques } \\
\text { suivantes: }\end{array}$ & Participants \\
\hline
\end{tabular}




\begin{tabular}{|l|l|l|}
\hline Horaires & Activités & Responsables/Présentateurs \\
\hline & $\begin{array}{l}\text { 1) Services de santé sexuelle et } \\
\text { reproductive adaptés aux } \\
\text { adolescents/jeunes. } \\
\text { 2) Problématique de l'éducation à la santé } \\
\text { sexuelle des adolescents/jeunes. }\end{array}$ & \\
\hline $13 \mathrm{~h} 30-14 \mathrm{~h} 30$ & Pause-déjeuner & Participants \\
\hline $14 \mathrm{~h} 30-15 \mathrm{~h} 30$ & Travaux de groupe (suite) & Participants \\
\hline $15 \mathrm{~h} 30-16 \mathrm{~h} 30$ & Restitution travaux de groupe & $\begin{array}{l}\text { Président Commission Santé } \\
\text { Assemblée Nationale }\end{array}$ \\
\hline $16 \mathrm{~h} 30-17 \mathrm{~h} 00$ & $\begin{array}{l}\text { Prochaines étapes } \\
\text { Clôture }\end{array}$ \\
\hline
\end{tabular}




\section{Liste des participants}

\begin{tabular}{|c|c|c|}
\hline $\mathbf{N}^{\circ}$ & INSTITUTION & NOM\&PRENOMS \\
\hline 1 & $\begin{array}{l}\text { Direction Générale de la Santé (DGS) représentant Madame le Ministre de la Santé } \\
\text { et de l'Action Sociale }\end{array}$ & Dr Pape Amadou Diack \\
\hline 2 & Assemblée Nationale ((Président Commission Santé) & Aimé ASSINE \\
\hline 3 & Assemblée Nationale & Mariama Diallo \\
\hline 4 & Assemblée Nationale & Madjiguéne Fall \\
\hline 5 & Assemblée Nationale & Khady Mané \\
\hline 6 & Assemblée Nationale & Mariama Mané \\
\hline 7 & Assemblée Nationale & AïyatouT aibou Baldé \\
\hline 8 & Assemblée Nationale & Ndiolé Diouf \\
\hline 9 & Assemblée Nationale & Seynabou Kébé \\
\hline 10 & Assemblée Nationale & Diya KANTE \\
\hline 11 & Conseil Economique, Social et Environnemental & Neynou Ndiaye \\
\hline 12 & DSRSE/MSAS & Marie Jésus Buabey \\
\hline 13 & DSRSE/MSAS & Mr Cheikh Bamba Diop \\
\hline 14 & DSRSE/MSAS & Dr Marieme Mady Ndiaye \\
\hline 15 & MSAS/Service juridique & Khady Seck \\
\hline 16 & Conseil Economique pour le développement de la femme & Nafissatou Mbodj \\
\hline 17 & Association des Parents d'élèves du Sénégal & Thierno Ndao \\
\hline 18 & Association des femmes handicapées & Ndeye Dagué Gueye \\
\hline 19 & Direction de l'Equité, de l'Egalité et du Genre/MFFE & Nafissatou Ndiaye \\
\hline 20 & Ministère de l'Education Nationale/Direction du Contrôle Médicale Scolaire (DCMS) & Mamadou Ndiaye \\
\hline 21 & Partners in Population and Development (PPD ARO) & Patrick Mugirwa \\
\hline 22 & Hewlett Foundation & Tabara Ndiaye \\
\hline 23 & Réseau National des Pairs Educateurs & Nene F Maricou \\
\hline 24 & Réseau Siggil Jigeen & Aida Ndoye Ba \\
\hline 25 & Groupe pour l'Etude et l'Enseignement de la Population (GEEP) & Khadijatou Thiam Tall \\
\hline 26 & UNFPA & Laty Ndoye \\
\hline 27 & ABT Associates & Dr Fodé Diouf \\
\hline 28 & Marie Stopes International (MSI) & Sanou Gning \\
\hline 29 & Association Sénégalaise pour le Bien-être familial (ASBEF) & Pape Momar Mbaye \\
\hline 30 & LE SOLEIL (Média/Presse écrite) & Maïmouna Gueye \\
\hline 31 & Service National de l'Education et de l'Information Pour la Santé (SNEIPS & Coura Seck \\
\hline 32 & Service National de l'Education et de l'Information Pour la Santé (SNEIPS) & Gora Niang \\
\hline 33 & Service National de l'Education et de l'Information Pour la Santé (SNEIPS) & Alioune Dieye \\
\hline 34 & Population Council & Nafissatou Diop \\
\hline 35 & Population Council & Babacar Mané \\
\hline
\end{tabular}

